\title{
Understanding the Nigerian Public Service Rules
}

\author{
John Olushola Magbadelo* \\ Director, Centre for African \& Asian Studies, Nigeria
}

Submission: May 21, 2020; Published: June 05, 2020

"Corresponding author: Dr. John Olushola Magbadelo, Lead Director, Centre for African\& Asian Studies, P.O. Box 6563, Garki Area 10 Post Office, Abuja, Nigeria

Keywords: Human enterprise; Organization; Nigerian public service; Constitution; Corruption; Nepotism; Tribalism/Ethnicity; Wrong Rules, Federal civil service commission; Recruitment

\section{Introduction}

The rules or regulations of any human enterprise or organization set out its guiding principles and policy, acceptable conduct, modalities for actualizing organizational objectives and the basic rights, duties and entitlements of its personnel. Any organization is as effective as the rules guiding its operations. The Nigerian Public Service can be likened to an organization of human activity which is governed and regulated by rules. The Public Service Rules (PSR) provides the operational framework, the regulatory principles and a charter of rights, privileges and duties of all public servants while detailing what sanctions erring conducts could attract. The PSR is a guidebook for employeeemployer relationship which also stipulates conditions of their engagement. The name of this document has changed overtime. From the colonial period to 1974, it was known as "General Orders" while from 1974 to January, 2000, it was called "Civil Service Rules" And from 2000 to date, it became known as the "Public Service Rules". The change of name of this guidebook goes beyond the name it is called, there are contextual and textual changes as well as structural changes which are all reflections of epochal changes resulting from the transition of the Service from one era to another.

The changes inherent in any new era ought to be reflected in the PSR because the country's Public Service is embedded in the web of societal influences which, to a very large extent, derived from global pressures that are impinging on the political economies across the world. The challenge is for the PSR to be responsive to changes as the need arises. If the public service system is faulty, it is either the rules are themselves faulty or that the rules are not well-applied. It could as well be that both the rules and their application are problematic. There is therefore a palpable linkage between the quality of our PSR, its application and the effectiveness of the public service system in our country.

In this paper, I do not intend to bore you with repetitive detailing of the provisions of the PSR but rather invite you on a critical adventure which will broaden your perspectives on the essence, quality and value of the PSR, and in particular, the efficacy of its application. At the end of this lecture, you should be able to ask critical questions about certain problematic aspects of the PSR in the light of the country's evolving political and economic realities.

\section{The Sources of the PSR}

The PSR like the country's 1999 Constitution is an imposed document with virtually no inputs from the civil servants on whom it is binding. It is not surprising that the PSR after 16 years of unbroken democratic governance since the emergence of the post-military era in 1999 still have some despicable provisions indicating hang-up or idiosyncrasy of the erstwhile military dictatorship. This is understandable because the PSR like the Constitution depicts the values and principles that were dominant in the military era but which ought to have been discarded with the advent of the current dispensation. The recent efforts at inviting inputs from MDAs for a planned revision of the PSR is perhaps a new reality that should be supported to ensure that the inputs are well-processed and incorporated into the PSR in deference to the tenets of representative public service systems as it obtains in other developed democracies of the world. 


\section{Contents of the PSR}

The PSR has 16 Chapters with some annexes which contain relevant information on parastatals and the Nigerian Foreign Service Regulations. Chapter One detailed the exemptions to the rules on appointment and highlighted the different statutory bodies that derived their powers from the Constitution (Rule010101). At Rules- 010102- 010105, the key concepts and terms are explained for easy comprehension of their use in the PSR. It is very important that officers acquaint themselves with the provisions of the PSR in order to function more efficiently on their schedules. In the subsequent sections an attempt would be made to present a panoramic view of the contents of the PSR.

\section{Rules of engagement (appointment, recruitment and transfers into the service)}

Chapter 2 of the PSR specifies the requirements for the different appointments into the Civil Service.

\section{Appointment}

The PSR clearly recognizes the authority of the Federal Civil Service Commission (FCSC) as the constitutionally empowered institution responsible for processing appointments to public offices in the Federal Civil Service. Where the MDAs recruit personnel on Gl. 01-06, it is done with the direction and authorization of the FCSC (See PSR -020101) The rule guiding appointment of junior staff on GL.06 and below in the MDAs is PSR - 020103 (a)- (c). The relevant rules guiding appointment of officers on posts graded GL. 07- 12 are detailed in PSR-020102 (i)-(v). These rules highlights the requisite qualifications to be possessed by prospective appointees as well as the processes involved.

PSR 020104 and 020105 are rules on promotion to all posts and incremental date of an officer appointed or promoted to a post would be more relevant in sections on promotion in the PSR.

PSR 020106 states that seniority in any department shall be determined by the entry date/ the date and timing on the assumption of duty certificate or as reflected in the appropriate register.

PSR 020107 prohibits the employment of unpaid staff.

PSR 020108 (i) - (ii) highlights the role of the Permanent Secretary as the custodian of staff personal records as well as the inalterability of the date of birth recorded by an officer on appointment.

\section{Recruitment}

Recruitment is defined as the filling of vacancies by the appointment of persons not already in the Public Service of the Federal Republic of Nigeria. It excludes the transfer of officers from other Public Service in the Federation to the Federal Public Service (See PSR 020201).
PSR 020202- 020204 detailed the types of appointment as trainees or pupil, probation in a pensionable post, non-pensionable contract to a non-pensionable post or against a pensionable post for a specified period, and acting appointment, while the conditions that could warrant each of these types of appointment and the processes involved and entitlements of affected officers are elaborated upon in PSR 020301- 020412.

PSR 020205- 020207- highlight the eligibility criteria for appointment into the Federal Public Service as well as the procedure.

\section{Transfers and secondment}

Section 5 of chapter 2 of the PSR detailed the processes involved in effecting transfer and secondment of officers. PSR 020502 defined "Transfer" as the permanent release of an officer from one scheduled service to another or from one class to another within the same service." Secondment" is defined as the temporary release of an officer to the service of another Government, approved body or any recognized International Organization or body for a specified period. PSR 020502- 020506 contain relevant information on the requirements to be satisfied by intending transferees or secondees.

\section{Rules regulating behavior or conduct of personnel}

Chapter 3 of the PSR contains a whole gamut of rules guiding the exercise of disciplinary control over officers in the Federal Public Service. Every serving officer is expected to acquaint himself/herself with these disciplinary rules and other regulations in force. Officers are to read these rules along with the "Guidelines on Appointments, Promotion, and Discipline" published by the Federal Civil Service Commission (FCSC). Although the FCSC is vested with the power to exercise disciplinary control over officers in the Federal Public Service, this power may be delegated to any member of the Commission or any officer in the Federal Civil Service.

PSR 030201- defined "General Inefficiency" as a series of omissions or incompetence, the cumulative effect of which shows that the officer is not capable of discharging efficiently the duties of the office he holds.

PSR 030202- 030208 detailed the processes of removing an officer from office on grounds of general inefficiency and the different punishments for related errant conduct.

PSR 030301-defined"Misconduct" as a specific act of wrongdoing or an improper behavior which is inimical to the image of the service and can be investigated and proved. It can lead to termination and retirement. Immoral behavior, unruly behavior, drunkenness, foul language, assault, battery, refusal to proceed on transfer or to accept posting, habitual lateness to work, deliberate delay in treating official document, failure to keep record, unauthorized removal of public records, dishonesty, negligence, 
membership of cults, sleeping on duty, improper dressing while on duty, hawking merchandise within office premises, refusal to take/carryout lawful instruction from superior officers, malingering, insubordination, discourteous behavior to the public are some of such offences.

PSR 030302-030314 highlighted the processes of commencing disciplinary action against an officer on grounds of misconduct and other sundry related offences in the service.

PSR 030401- defined "Serious Misconduct" as a specific act of very serious wrong-doing and improper behavior which is inimical to the image of the service and which can be investigated and if proven, may lead to dismissal. Serious acts of misconduct include: falsification of records, suppression of records, withholding of files, conviction on a criminal charge(other than a minor traffic or sanitary offence or the like); absence from duty without leave, false claims against Government officials, engaging in partisan political activities, bankruptcy/serious financial embarrassment, unauthorized disclosure of official information, bribery, corruption, embezzlement, misappropriation, violation of oath of secrecy, action prejudicial to security of state, advance fee fraud( Criminal code 419), holding more than one-full time paid job, nepotism or any other form of preferential treatment, divided loyalty, sabotage, willful damage to public property, sexual harassment, and any other act unbecoming of a public officer.

The disciplinary procedure for serious misconduct is spelt out in PSR - 030302- 030306. PSP 030407- 030601 detailed all other related offences which could be given the same consideration as serious misconduct.

\section{Rules detailing privileges, rights and entitlements- (promotion, medical, leave, allowances) \\ Promotion}

The PSR has provisions for promotion of serving officers. PSR-020701- 020708 highlight the conditions, requirements and procedure for promotion, pointing out the vital roles played by the Federal Civil Service Commission and the Office of the Head of Civil Service of the Federation in facilitating the successful conduct of the promotion exercise. This section of the PSR needs to be read along with the Guidelines on Appointment, Promotion and Discipline for deeper appreciation of the criteria for promotion which serving officers must satisfy to be eligible.

a) Maturity criterion: The minimum number of years that an officer must spend in a post before being considered eligible for promotion shall be as follows:

i. GL 06 and below - Minimum of 2 years

ii. GL 07-14 - Minimum of 3 years

iii. GL 15- 17 - Minimum of 4 years

b) Merit: Promotions shall be made strictly on the basis of competitive merit from amongst all eligible candidates. c) In all cases, a generally satisfactory record of conduct shall also be considered.

d) Responsibility for the promotion of officers shall be as follows:

i. GL 06 and below- by the Ministry/ Extra-Ministerial Office

ii. GL 07-14 - by the Ministry/Extra-Ministerial Office or the relevant staff pool subject to confirmation by Federal Civil Service Commission.

iii. GL. 15- 17 - by the Federal Civil Service Commission on recommendation from Ministry/Extra-Ministerial Office or the relevant pool routed through the Head of the Civil Service.

\section{Medical rules}

Medical Rules are clearly spelt out in Chapter 7 of the PSR. The chapter covers medical examination in the Service, confidential medical documents, procedure for carrying out medical test, facilities for medical treatment are highlighted in PSR-070101070201. Rule 070205 states that the Federal Ministry of Health may authorize a refund of medical expenses (including charges for maintenance) incurred by an officer while overseas on leave or on duty provided:

a) The illness was not due to the officer's own negligence;

b) The illness was attributable to conditions or the climate overseas;

c) The officer sought to avail himself of services of the local National Health Service(where applicable) and could not obtain the requisite attention there under within a reasonable time.

d) The officer informed the nearest accredited representative of the Federal Government of Nigeria at the earliest date possible that he was unable to obtain the requisite attention through the National Health Service; and

e) The officer showed reasonable diligence, expedition and economy in seeking and obtaining medical attention.

Rule -070206 detailed the processes and entitlements for medical treatment overseas and the different categories of public servants that are entitled to overseas medical check-up at Government expense as well as the approving authorities for the different categories of officers embarking on such check-ups. It is important to note that officers on Salary Grade Level 16 and above shall undertake mandatory medical check-ups locally once a year while officers on Salary Grade Level 12 to Grade Level 15 are entitled to medical check-ups locally once in two years. The resultant hospital bills of these check-ups are settled by the relevant Ministries/Extra-Ministerial Offices.

Rules-070301- 070313 are rules showing the responsibility of an officer to his employer in the event of illness, the responsibility of the Health Care Provider, Medical Board, etc. Rules - 070314070318 are Sick leave rules. The maximum aggregate sick leave 
which can be allowed an officer, who is not hospitalized, during any period of twelve months shall be forty-two(42) days. But, an officer who is hospitalized is entitled to a sick leave for a period up to three months in the first instance on the strength of a certificate of an approved Health Care Provider.

Rules -070401- 070402 highlighted the death benefits of an officer who died abroad or at home while still in active service. Related to this is Chapter 8 of the PSR on Compensation and Insurance, especially the Rule on loss of life (Rule- 080201).

\section{Leave}

Chapter 10 of the PSR contains the different types of leave that an officer could apply for as the need arises. "Leave" is defined as the authorized absence of an officer from duty for a specific period. Rule - 100201 listed the different types of leave to include Annual leave, casual leave, maternity leave, study leave with or without pay, leave of absence, etc.

Rule 100203- States that Annual leave shall be granted to an officer in accordance with his grade level as follows:

a) GL. 07 and above- 30 calendar days.

b) GL. 04- 06 - 21 calendar days.

c) GL. 03 and below- 14 calendar days.

Rule- 100217 defined Maternity leave as the authorized absence from duty of a serving female officer granted by a superior officer on account of pregnancy covering the prenatal and postnatal periods. A female officer that is pregnant is entitled to 16 weeks maternity leave at a stretch beginning not less than 4 weeks from the expected date of delivery with full pay. The officer is must present a medical certificate indicating the expected date of confinement two months before that date( see Rule- 100218).

Any female officer who is nursing a child shall be granted two hours off-duty every day. This facility shall be granted up to a maximum period of six months from the date she resumes duty from maternity leave (Rule- 100219).

\section{Allowances}

Chapter 13 of the PSR contains all the allowances that officers in the Public Service are entitled to. An allowance is defined as a monetary benefit other than salary granted to an officer for a specific purpose.

Rule- 130102 listed all the allowances payable to officers in the Federal Public Service including kilometer allowance, disengagement allowance, Hotel Accommodation allowance, duty tour allowance, estacode allowance, books allowance, projects allowance, overtime allowance, etc. These allowances are periodically reviewed in consonance with the economic realities in the country. Such periodic revisions are communicated to staff of the MDAs through circulars issued by the relevant offices in the Federal Public Service.

\section{Rules of disengagement- termination, resignation, retirement, dismissal, retrenchment}

As there are rules guiding entry into the Service, there are rules on how to exit the Service. PSR- 020801 detailed a whole gamut of processes and conditions for leaving the Service with or without compensation.

\section{Termination/ relinquishment of appointment}

Rules -020802 and 020803 address the possibility of an officer's relinquishment of his appointment during the probation period or as a result of his inability to secure confirmation of his pensionable appointment at the end of the probationary period. Also Rule-030208 and 030301 point out that an officer's appointment can be terminated for inefficiency or misconduct.

\section{Resignation}

Rule -020804-detailed the liabilities of an officer who resigns his appointment to include the following:

a. forfeit all claims to vacation leave- any vacation leave or passage privileges granted will be ex-gratia;

b. refund to the Government in full any sum of money which he/ she may be owing to Government or which, under the provisions of other Rules or agreements entered into with Government, is refundable to Government for his/her not discharging the obligations set out in such agreement; provided that any or all of such refunds may be waived at the discretion of the Government The PSR also observed that the provisions of Regulation 15 of the Pension Reform Act 2004 are relevant.

\section{Retirement}

Rules -020806 stated two grounds on which an officer may be retired as:

a) Failure in promotion examination on three consecutive attempts on the same grade with on-the -job performance assessed to be below average;

b) When the service of an officer is no longer required due to the abolition of his office consequent upon re-organization of the office or palpable redundancy. The implementation of reforms in the Public Service has led to other forms of exiting the Service including retrenchment, downsizing, and rightsizing.

Rule-030301 points out that the commission of act of wrongdoing or misconduct could lead to retirement when investigated and proven.

\section{Compulsory retirement}

Rule- 020810 states that the compulsory retirement age for all grades in the Service is 60 years or 35 years of pensionable service whichever is earlier. 


\section{Tenure policy}

A Director shall compulsorily retire upon serving eight years on the post; and a Permanent Secretary shall hold office for a term of four years and renewable for a further term of four years, subject to satisfactory performance, and no more (Rule- 020810).

\section{Dismissal}

a) Rule -030401 states that the commission of serious misconduct could lead to dismissal when investigated and proven. In Rule- 030407, states that an officer who is dismissed forfeits all claims to retiring benefits, leave or transport grant, etc subject to the provisions of the Pension Reform Act, 2004.

b) Rules- 020807 - 020809 highlight requirements for processing retirement benefits. Rules- 020901- 020905 detailed the processes for applying and requirements for receiving the Certificate of Service on leaving the service.

\section{Death of an officer}

Rules 070401-070402 indicate the possibility of an officer's exit from the Service on account of death.

\section{Miscellaneous Provisions in the PSR}

The following Chapters of the PSR should be read by officers:

a) Chapter 9 on "Petitions and Appeals" clearly chronicled the rules and processes of making representations to the Government;

b) Chapter 11 on "Free Transport Facilities within Nigeria".

c) Chapter 12 on "Courses of Instruction within and outside Nigeria”.

d) Chapter 14 on "Inventions".

e) Chapter 15 on "Reward for outstanding work".

f) Chapter 16 on "Application of the Public Service Rules to Federal Government Parastatals".

g) General Appendix C -“ Nigerian Foreign Service Regulations".

\section{Areas / Sections requiring Amendments or Deletion}

The Civil Service has been run over the years as an institution that appears impervious to change and innovation. It is this attitudinal disposition that shuts the door against the introduction of new regulations and rules or revision of old rules in the light of the obvious fact that some extant rules and regulations had become irrelevant and outdated. For instance, some provisions of the Public Service Rules (PSR) which, understandably, were a reflection of the dominant influences of the military era but which at the end of that era in 1999 when democratic rule was restored, ought to have been expunged outright from the PSR, were still retained despite the fact that the PSR had been reviewed four times since the inception of democratic rule in the country (i.e. in 2000, 2004, 2007 and 2008). To drive home this point, some of the problematic provisions in the PSR and the reasons why they should be deleted when viewed against other developments, are detailed hereunder:

a) Oath of Secrecy- Rule 030415: "It shall be the duty of every Permanent Secretary/Head of Extra-Ministerial Office to ensure that all officers, employees and temporary staff in his /her Ministry /Extra-Ministerial Office who have access to classified or restricted papers have signed the Oath of Secrecy in the appropriate form before they are granted such access and that declaration so signed are preserved".

This rule seems to have outlived its relevance in the light of its non-application over the years. This writer has worked in sensitive government offices and has handled classified and restricted documents in the course of his official assignments in the Cabinet Office for seven years and has never been made to sign any oath of secrecy form. In actual fact, it could be safely argued that the Government has stopped the production of the oath of secrecy forms, perhaps, since the commencement of democratic rule.

b) Unauthorized disclosure of official information- Rule 030416: "Every officer is subject to the Official Secrets Act (Cap. 335) and is prohibited from disclosing to any person except in accordance with official routine or with the special permission of Government, any article, note, document or information entrusted to him/her in confidence by any person holding office under any Government in the Federal Republic of Nigeria, or which he/she has obtained in the course of his/her official duties. Similarly, every officer shall exercise due care and diligence to prevent the knowledge of any such article, note, document or information being communicated to any person against the interest of the Government".

This rule prohibits the disclosure of Government's official secrets which were so much during the military era. But, with the emergence of democracy and its relative transparency borne out of its representativeness, such so-called official secrets are the subjects of vibrant and open public discourse in the public domain. Moreover, in May, 2011, the Nigerian Government signed into law the Freedom of Information Bill, thereby making Nigeria the second country in West Africa to have a Freedom of Information (FOI) law [1]. The FOI Act empowers Nigerians to request for any information concerning government's actions and activities, to unearth facts, battle corruption and hold officials and institutions of government accountable [2]. Although, the FOI Act is enormously empowering, the Nigerian Civil Societies Organizations, Human Rights Advocacy groups and other pressure and interest groups have not fully taken advantage of it to make Government more accountable to the citizenry.

c) Publication and public utterances- Rule-030421: "Except in pursuance of his/her official duties, no officer shall, without the express permission of his/her Permanent Secretary/Head of ExtraMinisterial Office, whether on duty or on leave of absence: 
i. $\quad$ act as the editor or take part directly or indirectly in the management of or in any way make financial contribution to any newspaper, magazine or journal except Departmental or staff magazine, professional journal, and publication by voluntary organizations;

ii. Contribute to, whether anonymously or otherwise, publish in any newspaper, magazine or periodical, or otherwise publish, cause to be published in any manner anything which may reasonably be regarded as of a political or administrative nature;

iii. $\quad$ Speak in public or broadcast on any matter which may reasonably be regarded as of a political or administrative nature;

iv. Allow himself/herself to be interviewed or express any opinion for publication on any question of a political or administrative nature or on matters affecting the administration, public policy, defence or military resources of the Federation or any other country...."

This provision is palpably and blatantly offensive to the spirit and letters of the 1999 Constitution of the Federal Republic of Nigeria. According to Section 39(1) of the Constitution which says that: "Every person shall be entitled to freedom of expression, including freedom to hold opinions and to receive and impart ideas and information without interference", and subsection(2) which says: "Without prejudice to the generality of subsection (1) of this section, every person shall be entitled to own, establish and operate any medium for the dissemination of information, ideas and opinions" [3], it is clear that the PSR provision under reference cannot be reasonably justified in a democratic society, and therefore should be deleted

\section{Why the Rules are not so Effective}

a) Corruption: The bane of Nigerian society is corruption. The Nigerian Public Service is embedded in the web of societal influences and therefore cannot be impervious to the raging forces of corruption. Almost all the processes in the Service are affected by corruption. Cash for jobs, cash for promotion, cash for confirmation, cash for involvement in programmes, etc summarizes the pervasive influence of corruption on the systems in the Civil Service of the country. In this circumstance, the PSR cannot be said to have a foothold on the operations in the Service.

b) Nepotism: This has to do with preferential considerations wherein the PSR is applied differently to different people. This situation describes the existence of double standards instead of making the rules have uniform or universal application.

c) Tribalism/Ethnicity: The ethnic diversity and cultural configuration of Nigeria seem to predispose some unscrupulous officials to discriminatory practices on grounds of ethnic sentiment thereby tending to favour only those from their ethnicity even to the extent of violating extant rules.

d) Faulty application: This could result from either deliberate decision to misapply the rules or innocent misapplication of the rules on account of inefficiency and incompetence which were borne out of lack of understanding of the rules and their objectives.

e) Federal Character Principle: This principle which is meant to ensure some form of ethnic balancing in appointments in Federal Government Establishments or institutions has overtime been wrongly observed. The principle is being applied to promotion of personnel which ought to be based on competitive merit.

f) Wrong Rules: Every society is in a state of flux. The only constant thing in life is change. Therefore, as the society changes, its rules cannot afford to be static. The Nigerian society which is the operating environment of the Nigerian Public Service has transitioned to democracy since 1999, thereby necessitating the need for the Public Service Rules to be thoroughly divested and stripped of those anti-democratic provisions that are conflicting with the fundamental rights of the citizenry.

\section{Concluding Remarks}

The Public Service Rules (PSR) as a guiding legal instrument has helped in regulating the operations and behavior of all the operatives in the Service. Without the rules, anarchy would have prevailed. The wrong application or non -application of the rules does not in any way detract from the importance of the rules in the management of the country's Public Service. The shortcomings or inadequacies of the PSR and the larger problems of the society impinging negatively on public sector governance and its application of rules are issues which should be addressed as a way effecting reforms and institutionalizing same in the Nigerian Public Service. Having a good PSR is one thing, being willing and able to implement it impartially is another. This would require not just institutional reform but attitudinal reorientation.

\section{References}

1. Nigeria's Freedom of Information Act.

2. Kayode Ajulo, FOI Act: The Challenge of Official Secret Act. A Paper presented at a Workshop organized by Nigeria Press Council in conjunction with NUJ.

3. (2011) 1999 Constitution of the Federal Republic of Nigeria (with Amendments), No. 42. 


\begin{tabular}{l} 
Your next submission with Juniper Publishers \\
will reach you the below assets \\
- Quality Editorial service \\
- Swift Peer Review \\
- Reprints availability \\
- E-prints Service \\
- Manuscript Podcast for convenient understanding \\
- Global attainment for your research \\
- Manuscript accessibility in different formats \\
( Pdf, E-pub, Full Text, Audio) \\
- Unceasing customer service \\
Track the below URL for one-step submission \\
https://juniperpublishers.com/online-submission.php \\
\hline
\end{tabular}

